(6) OPEN ACCESS

${ }^{1}$ Chubu Rosai Byoin, Nagoya, Japan

${ }^{2}$ Department of Respiratory Medicine, Hyogo Prefectural Amagasaki General Medical Center, Amagasaki, Hyogo, Japan

${ }^{3}$ Department of Diagnostic Pathology, Hyogo Prefectural Amagasaki General Medical Center, Amagasaki, Hyogo, Japan

\section{Correspondence to} Dr Yuki Haruta(Inoue), gamann92@gmail.com

Accepted 21 July 2016

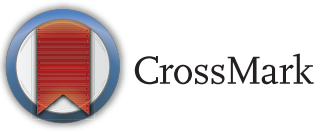

To cite: Haruta(Inoue) $Y$ Kataoka Y, Nikaido J, et al. BMJ Case Rep Published online: [please include Day Month Year] doi:10.1136/ bcr-2016-216232

\title{
Histological transformation from non-small cell to small cell lung carcinoma
}

\author{
Yuki Haruta(Inoue), ${ }^{1}$ Yuki Kataoka, ${ }^{2}$ Junichi Nikaido, ${ }^{2}$ Naoki Nakajima ${ }^{3}$
}

\section{DESCRIPTION}

A 58-year-old woman with no history of smoking was admitted to our hospital with exacerbation of cough. CT of the chest revealed a left upper lobe lung tumour. Bronchoscopic biopsy of the tumour revealed stage IV poorly differentiated adenocarcinoma (figure 1) with epidermal growth factor receptor (EGFR) gene mutation (L858R point mutation). After cytotoxic chemotherapy (cisplatin and pemetrexed) as first-line therapy, disease progression was identified. For the next 3 years, she was treated with erlotinib, an EGFR tyrosine kinase inhibitor (TKI). Regimens were changed several times (cisplatin, gemcitabine, docetaxel and

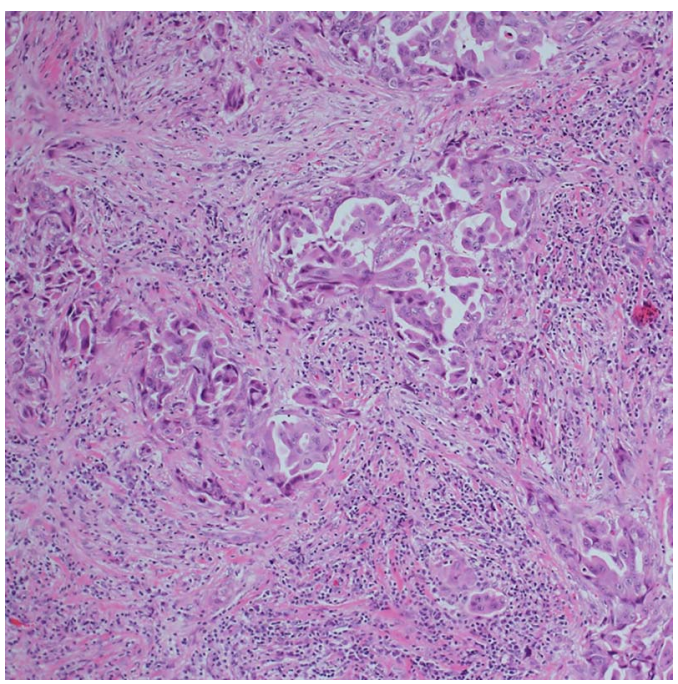

Figure 1 H\&E staining.

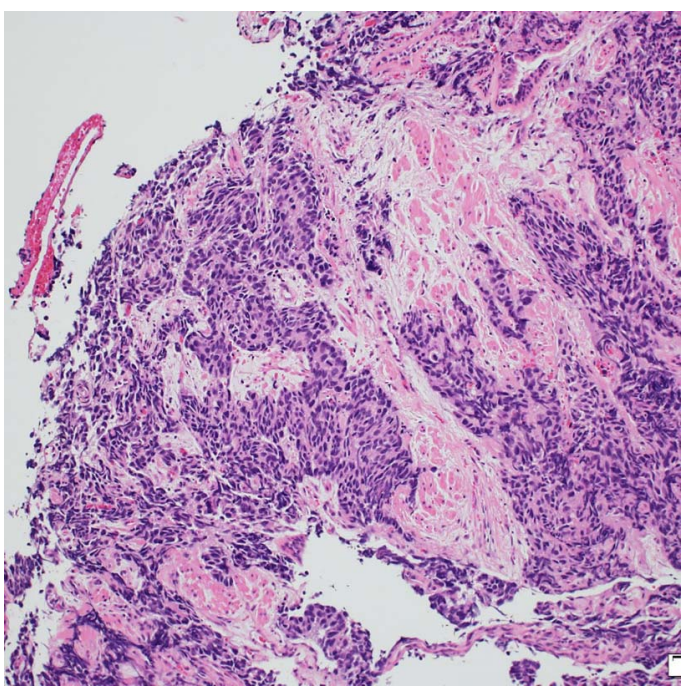

Figure 2 H\&E staining. afatinib) due to disease progression or adverse effects. After 2 months with afatinib, disease progression was again noted. We once again performed bronchoscopic biopsy of the primary tumour, and small cell lung cancer (SCLC) was confirmed from histopathological examination (figures 2-4). Levels of tumour markers such as progastrin-releasing peptide and non-specific elastase were elevated. Moreover, a second examination again detected the EGFR gene mutation (L858R point mutation without T790M point mutation). Amrubicin was administered, resulting in radiologically stable disease. Most cases of acquired resistance to EGFR-TKI arise from the emergence of T790M

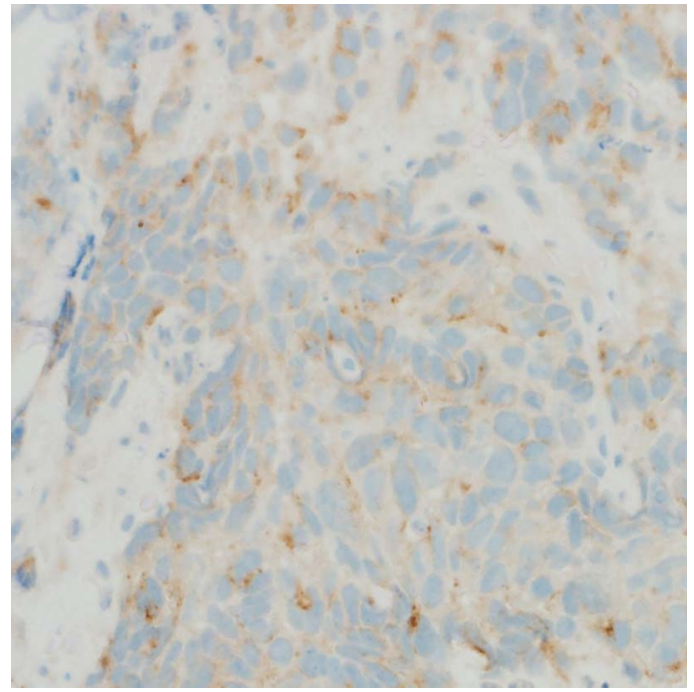

Figure 3 Chromogranin A staining.

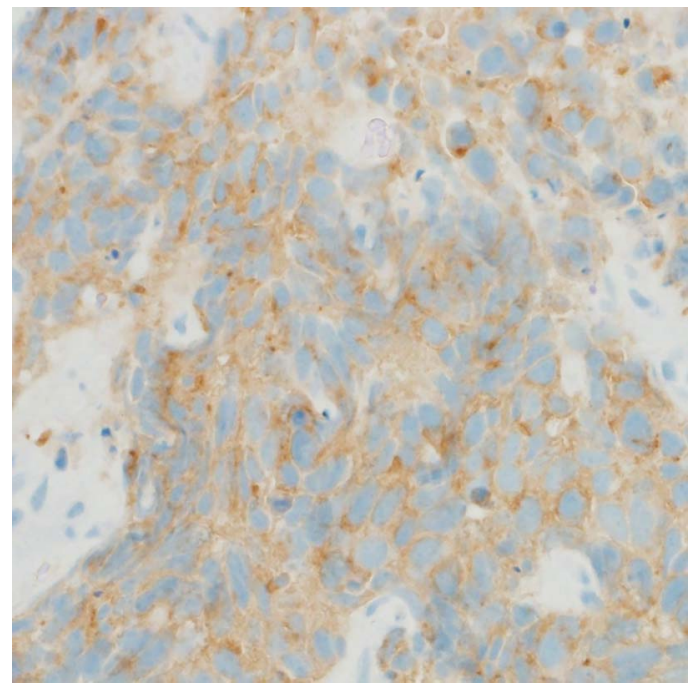

Figure 4 Synaptophysin staining. 
mutation, and morphological transformation to SCLC is rare. ${ }^{1}$ After the failure of EGFR-TKI, rebiopsy of the tumour is warranted to determine the next treatment strategy.

\section{Learning points}

- After the failure of epidermal growth factor receptor-tyrosine kinase inhibitor (EGFR-TKI), rebiopsy of the tumour should be performed to determine the next treatment strategy.

- But it is unclear when to perform rebiopsy after EGFR-TKI failure.
Contributors $\mathrm{YH}, \mathrm{JN}$ and NN participated in patient care. $\mathrm{YH}$ wrote the manuscript and $Y K$ revised it.

Competing interests None declared.

Patient consent Obtained.

Provenance and peer review Not commissioned; externally peer reviewed.

Open Access This is an Open Access article distributed in accordance with the terms of the Creative Commons Attribution (CC BY 4.0) license, which permits others to distribute, remix, adapt and build upon this work, for commercial use, provided the original work is properly cited. See: http://creativecommons.org/licenses/ by/4.0/

\section{REFERENCE}

1 Cortot $A B$, Jänne $P A$. Molecular mechanisms of resistance in epidermal growth factor receptor-mutant lung adenocarcinomas. Eur Respir Rev 2014;23: $356-66$.

Copyright 2016 BMJ Publishing Group. All rights reserved. For permission to reuse any of this content visit http://group.bmj.com/group/rights-licensing/permissions.

BMJ Case Report Fellows may re-use this article for personal use and teaching without any further permission.

Become a Fellow of BMJ Case Reports today and you can:

- Submit as many cases as you like

- Enjoy fast sympathetic peer review and rapid publication of accepted articles

- Access all the published articles

- Re-use any of the published material for personal use and teaching without further permission

For information on Institutional Fellowships contact consortiasales@bmjgroup.com

Visit casereports.bmj.com for more articles like this and to become a Fellow 